\title{
Analysis of Formation in Communicative Competences for the Medical Act in Universidad de Antioquia Medicine School Undergraduate Program
}

\author{
José Antonio García Pereáñez ${ }^{1,2}$ \\ ${ }^{1}$ American University Corporation, Medellin, Colombia \\ ${ }^{2}$ University of Antioquia, Medellin, Colombia \\ Email:jgarciap@coruniamericana.edu.co,jantonio.garcia@udea
}

How to cite this paper: Pereáñez, J.A.G. (2016) Analysis of Formation in Communicative Competences for the Medical Act in Universidad de Antioquia Medicine School Undergraduate Program. Journal of Biosciences and Medicines, 4, 76-88.

http://dx.doi.org/10.4236/jbm.2016.412012

Received: November 4, 2016 Accepted: December 1, 2016 Published: December 8, 2016

\begin{abstract}
This research study was conducted at the undergraduate program of the Medicine Faculty of Universidad de Antioquia. Its main purpose was to analyze the training in communication skills for the medical act. To this purpose, a triangulation between a representative survey of the students, some interviews and focal groups between students and professors, and an analysis of a curricular document on the contents of communication as a generic skill were done. This study allowed us to conclude that the definition of generic competence in communication cannot be established without the participation of the medicine curriculum actors, and that it is paramount to integrate this learning to this university program. The result of the present study is a proposal to include the communicative competence for the medical act in the curriculum of the Medicine Faculty of Universidad de Antioquia.
\end{abstract}

\section{Keywords}

Communication Skill, Medical Act, Medical Education, Generic Competence

\section{Introduction}

This study, started in 2014, was aimed to look into the pedagogical exercise in communicative competences for the medical act in the Medicine Faculty of Universidad de Antioquia. It was intended to verify if this subject is part of the curriculum and how it is integrated to the teaching in the undergraduate program. Our main purpose is to problematize and qualify the current training of the medical staff. It is also intended to 
conduct an analysis of the medical teaching practices and the training in communicative competences in the courses of ActoMédico (Medical Act) of the curriculum as well as in the basic courses of that medicine program. This purpose was fulfilled through a qualitative intervention with a very detailed document revision supported by the current study plan of this faculty. The information was obtained through interviews with students and professors and socialization with focal groups. This information was classified and categorized; a contrast from the sources, a triangulation of the participants, compared readings according to the conceptual referents and a setup of reply patterns were also done.

This study did not represent any risk for the people who were inquired about their perceptions in the training of communicative competences in the doctor-patient relation. According to the current norm in Colombia, Resolución 4830 de 199 [1] which regulates the health research in the country, some documents were observed: Artículos 26, 14 and 11, in relation to the consent form, freedom to participate and the all-risk exception. We complied with the recommendations of the Helsinki Declaration 2008 [2] in relation to the use of data obtained from any research with human beings, and the Convención de Oviedo which advocates for the right to privacy of the researched subjects and the confidentiality of the data. Likewise, we observed the finest prescriptions about privacy and confidentiality of information. This is the reason why the professors of the communication area were not in charge of the surveys and interviews with the students nor were moderators of the forums. We assure to the scientific community that this information will be kept safe, and that the person who interpreted it does not have any interest conflict with those who provided it. Additionally, the student who typed the information signed a compromise of confidentiality, and the students and professors who participated in this research study gave their informed consent.

The methodology was developed through the comprehensive paradigm with triangulation of techniques. In the first section, the problem is stated; in the following sections the theoretical framework, the methodology, the results and the analysis are presented. Any kind of pressure was exerted on anyone to ask for participation in the study. All of them were informed of their right to leave anytime they wanted to. The researcher assumes the ethical responsibility of the data use, keeping the anonymity of the participants for which some codes for the information management were used.

\section{Statement of the Problem}

The present study is justified because the mission of the Medicine Faculty of Universidad de Antioquia is the integral training of the medical doctors that this institution provides to the society in order to have a positive impact on the individual and collective welfare of the population they serve as professionals. The confidence relationship that is established in the meetings between medical doctors and patients (in promotion, prevention, treatment and rehabilitation activities), and that leads patients to modify the risk factors and adhere to the treatments suppose the participation of the patient in some decision-making based on the sympathetic relations with the health professional; 
that is, the quality of the medical attention influences the result of individuals' health. This happens in a limited manner, though because it also depends on genetic, biological and lifestyle factors, which at the same time involves cultural and social elements as well as health services, as Lalonde stated [3].

The Medicine Faculty of Universidad de Antioquia includes the communicative competence in its curriculum as a cross-cutting pillar in the integral training of the students. This is the main purpose in including courses in the first two semesters and modules integrated to the subjects of Acto Medico in the fifth and sixth semester. Additionally, some topics such as the communication of bad news and the preparation for death are proposed for discussion in the deepening courses. The students also learn to interact with patients in practices in which they take their professors as learning models.

This research proposal has some precedents in the experiences of the EDUSALUD research group of the same faculty. They focused on didactics and curriculum research lines; about the analysis and evaluation of the current curriculum. In the Medicine program curriculum, communication has been revised in some works carried out in the faculty: Salazar \& Cols found that the undergraduate students who are in their last year perceive their professors as learning models of communication with the patient. However, the facts contradict this discourse because although they are aware of the participation of the subject in the assistance meetings and the clinic practice, the supremacy of the biomedical aspects is evident under these circumstances; a fact that does not favor the communicative participation. In another research study that evaluated the current curriculum, the students stated that they would like the communication courses of the first semesters to be appropriate spaces for discussing the doctor-patient relationship instead of focusing on the components of writing and the interpretation of literature works, as it is currently done.

Finally, in a research exercise conducted in 2012, the students of the sixth semester perceived communication from two different positions: a horizontal one; of mutual agreement and bidirectional growth and a vertical one in which the doctor is the owner of knowledge while the others are passive receivers of this knowledge. The Medicine Faculty does not have any research work in which the communicative process with the patients or the communication between professors and students during the training practices is described or explained. Taking into consideration the perception of professors and students about this serious aspect, it is important to work on it in order to better understand how this formative process is being currently done to eventually impact it in a positive way.

According to professors Leonor Galindo and María Elena Arango [4], the aforementioned faculty views the curriculum as a training and construction project, inspired in articulated and systematic concepts of pedagogy, developed through actions with sense and formative intention. The current curriculum of this undergraduate program is aimed at making excellent general doctors; good ethical citizens that keep in mind the universal and singular culture. Professionals with the capacity to do interdisciplinary 
work to intervene the health-disease process in the context of the human vital cycle through promotion, prevention, treatment and rehabilitation actions. Professionals who have influence over the social reality as change agents that improve the life quality of citizens and the society; that is, integral professionals in both being and doing. Autonomous, reflexive and critical individuals with the capacity to listen, question and enjoy; to build knowledge in an inter-subjective manner, to build and analyze the information as well as adequately use technology. Professionals who favor democratic relations among members of the society, and all the estates of the university community.

The concept of "competence" was incorporated in the curriculum without any methodological rigor or theoretical support, besides being based on insufficient literature review. In order to justify the learning through "competences", the definition by ElviaMaría Gonzalez [5] was selected: "competence understood as the capacity of the potential being to solve problems that emerge from necessities, obstacles, lacks, wishes, with the use of knowledge that methodologically emerge from logical, aesthetic and ethical processes". The main researcher of this study disagrees with this concept, since from his perception, competences as components of human development become part of thoughts, behaviors, attitudes and emotions. Competence defined just as potential capacity diminishes the human dimension and postulates it to here and now. Additionally, it seems that we would have to wait for a problematic situation to appear for the competence to emerge and then use the logical, aesthetic and ethical processes. On the other hand, the classification of the competences into basic, specific and generic-the latter selected as such without a clear bibliographical support-was defined by the curriculum committee of the aforementioned university with a very relevant purpose in the students' training.

The context described above was the argumentative base to define "communication" as a generic competence in the undergraduate program's medical education of the Medicine Faculty of Universidad de Antioquia; "capacity that not only includes the knowledge of the language but also the ability to use it; its acquisition is mediated by the social experience, the necessities, the motivation and action". This position is problematic because the training in competences is defined without being consulted and without a theoretical approach. It is even more problematic when some of the competences are classified into "generic" - communication is one of them-and it is justified with only one reference: "a mediation that can promote and accompany our students' learning; that is, to foster the ability to appropriate the world and themselves". The main researcher of this study is part of the University of Antioquia in the communication area of the Medicine Faculty and he considers that communication as a generic competence in the training of undergraduate students should be analyzed through a research study with methodological rigor and consulting the main actors: students and professors.

The question that guides this research study is what is the state of the training in communicative competences for the medical act in the undergraduate program of the Medicine Faculty of Universidad de Antioquia? 


\section{Theoretical Framework}

A rigorous search for specialized bibliography was carried out related to the purpose of this work and it was clear that the theoretical guidelines of this research are coherent with consulted texts. Reviewing the literature that contextualizes the problem, it was found that Casasbuenas [6] proposes reflections on formation in communicative competences for the medical act, as a result of the worry for failures that not only physicians but also users have been observing. These failures, according to the author, have been diminishing the relation that existed before, that although it was not perfect, it allowed the three human groups a certain confidence and satisfaction level. What both community and individuals miss is not the lack of capacity of physicians of their technical preparation for diagnosis, but the affection and closeness with their patients. People do not feel physicians close to them, neither they feel their comprehension or accompanying in the difficult moments of sickness or in the choosing and application of the most appropriate programs to prevent diseases.

According to Rodríguez [7], communicative skills are a must to establish a satisfactory physician-patient relation thus obtaining the necessary information for a correct diagnosis. Furthermore, it is important to have a skillful communication with patients. In Rodríguez's work, an adaptation of communication skills used in the pedagogical environment to the context of the medical questioning was proposed. They were grouped as follows: skills for communicating, skills for observing and listening, and skills for establishing a good relation with patients. Likewise, Aguirre [8] also proposes a conceptual approximation to the study of a communicative competence, from the criteria of some authors with different approaches. Theoretical systematization of the topics by researchers is very important in order to improve the formation quality of future physicians, according to transformations in their course of study. This work defined the communicative skill as a potentiality of subjects to properly relate with others, expressed in three dimensions: affective-cognitive, communicative, and socio-cultural. Aguirre analyzed different approaches and highlighted the importance of acquisition and development of a communicative skill for the success of the medical interaction process in different scenarios.

On the other hand, Soto [9] stated that every professional needs to communicate well in order to reach the objective of his work and, consequently, he should use tools that the communication world offers. Physicians are constantly communicating with other people. It should be taken into consideration that an effective communication consists in spreading information to specific communities, listen to their needs and properly answer their questions. The most relevant conceptual axis of this research is the human communication theory. Watzlawick [10] states that, provided that the communication is a way of behavior, its learning will be easier if students find in their teacher someone who teaches them closing attitudes with respect, affection, and to whom they pay attention. In this way in each medical action in which they participate, they will be learning both technical and human skills and acquiring emotional and human attitudes for their better performance. 


\section{Methodology}

According to Maria Eumelia Galeano [11], any social research, as an inquiring, reflection, construction, re-significance or systematization of knowledge, is aware of a starting point; a first step that can be stated by following at least two strategies: the first has to do with understanding the beginning as the first of a series of successive steps, each of them as a prerequisite of the following one. The second one states that the beginning is a task among others, all of them responsible and linear somehow.

This research has an experimental feature, with a qualitative approximation circumscribed to the phenomenological field through the analytic method: listen and intervene. The internal logic of the communication in medical training was also considered. The analytic method was used by separating a phenomenon into its elements (in this particular case, the training in communicative competence for the medical act) in order to understand and reconstruct its relations, from the empiric and concrete to the abstract and symbolic. It should be considered that the expression of a subjective structure is manifested through the permanent appearance of the word-spoken or written-, as well as through non-verbal communication which make appear the dialectic contrast between the discourse and the experience of the medical act, leading to its comprehension an re-articulation. For the interpretative analysis of the categories and findings of this study, the referents of La comunicación no verbal by Flora Davis [12], Contra el método by Paul Feyerabend [13], as well as La pedagogía del conocimiento by Rafael Florez [14], ¿Quées la crítica? by Miguel Foucault [15] and La educacióncomopráctica de la libertad by Paulo Freir [16] were useful. In Table 1: the objectives and the evaluation indicators.

For this study, students and professors of the undergraduate programs were called, who freely signed the informed consent. Students registered in the basic subject Medical Action (V term), Communication area, subjects I and II, component of Bioethics

Table 1. Dimensions to be developed.

\begin{tabular}{|c|c|c|}
\hline Objective & Indicators Dimensions & $\begin{array}{c}\text { Techniques and } \\
\text { Sources }\end{array}$ \\
\hline $\begin{array}{l}\text { To describe the relation between medical } \\
\text { teaching practices and the formation in } \\
\text { communicative competences in the subjects } \\
\text { of Medical Act, which belong to the current } \\
\text { curriculum communication area and } \\
\text { components of bioethics and humanities, } \\
\text { according to the analytical methods. }\end{array}$ & $\begin{array}{l}\text { Search for the concept } \\
\text { of competence. } \\
\text { Relations between medical } \\
\text { education and the formation in } \\
\text { communicative competences for } \\
\text { the physician-patient relation. }\end{array}$ & $\begin{array}{l}\text { Interviews to } \\
\text { professors and } \\
\text { students. } \\
\text { Survey to } \\
\text { focus group l }\end{array}$ \\
\hline $\begin{array}{l}\text { To evaluate the concept "communication } \\
\text { generic competence" in Medicine } \\
\text { undergraduate program, at the light } \\
\text { of the findings of this study. }\end{array}$ & $\begin{array}{l}\text { How the formation in } \\
\text { communicative competences in } \\
\text { the physician-patient relation is } \\
\text { expressed in the curriculum and } \\
\text { in Universidad de Antioquia } \\
\text { Medical Education Program }\end{array}$ & $\begin{array}{l}\text { Semi-structured } \\
\text { interview, focus } \\
\text { groups. } \\
\text { Survey }\end{array}$ \\
\hline
\end{tabular}


and Humanities (from I to IV term) and Social Pediatrics (VI). 302 students participated in the study (280 through surveys, 12 through interviews and 10 in focus groups). 29 professors of basic and professional areas also participated.

\section{Objectives}

The objectives of this study are to analyze the training that is imparted in the undergraduate program of the Medicine Faculty of Universidad de Antioquia and to describe, according to the analytic method, the relation between the medical teaching practice and the training in communicative competences provided in the medical act courses of the current curriculum, Communication Area and Humanities and Bioethics Components. Another objective is to evaluate, based on the findings that this study will bring, the concept of "communication generic competence" in the medicine undergraduate program.

\section{Data Collection Techniques and Instruments}

Interviews to professors: After the survey was completed, interviews oriented with a guide of questions were carried out to professors of different curricular areas in the two cycles of the curriculum.

Conversations with students: These were semi-structured interviews, rather informal, with the purpose of knowing student's perceptions on the teaching of communicative competences for the medical action. The number of interviews was defined for the saturation of categories.

Survey: Between October, 2014 and March, 2015, a survey consisting in open and close questions was applied to students, being the most representative sample of this study.

Document revision: Documents of Medicine school curriculum were under a rigorous analysis as well as those documents resulting from research studies related to undergraduate studies on assistance in health carried out by 6 EDUSALUD group.

Wit ${ }^{1}$ Movie: Since, this movie has been used in the subject Communication I and Communication II of Medicine undergraduate program. The movie shows scenes of a woman suffering from a terminal cancer, in the middle of interests of her physician for research and the medicine students for knowledge. The short film shows the language of suffering and the patient's impotence, as well as asymmetric and imposing relations of medical personnel, through the "informed consent."

Focus Groups: The discussions about the medicine undergraduate students' and professors' perceptions towards the teaching of communicative competences for the medical act were proposed in two separate groups, one with the professors and another with the students.

Journal: During the time of the study a journal was kept; this is an instrument to constantly register situations related to the research process.

All these instruments were under a pilot proof, which allowed evaluating their content,

\footnotetext{
${ }^{1}$ Wit. Director: Mike Nichols; USA; 2001.
} 
language, and information. After that, necessary adjustments for its definitive application were carried out. The application of instruments allowed triangulating and contrasting information by agents and instruments, which contributed to the credibility of results.

\section{Results and Analysis}

This study favored the triangulation methodological strategy Arias [17] from a survey prepared for undergraduate students and the survey to professors. Interpretation by the comprehensive paradigm Galeano [11] was proposed. The analysis of the curriculum of the School on the content of "communication" as a generic competence was also favored. The survey was applied to students and professors, each one with its own characteristics, with open and close questions. There was a search for finding information with the representative survey and then interviews and focus groups were used in order to widen the gathering of information.

Students' representative sample-as stated before-was 302, applying "randomized simple sampling" technique on a population of 1574 students registered in the second academic term, 2014. Selection criteria of the sample were maintained: reliability 95\%, error of $5 \%$ and proportionality for the expected value and error of $4.88 \%$. In relation to questions, which could be replied with three answers, there was a calculation in order to weigh the result of each category in the three options, according to the frequency, and a score was provided. The following scale was used: 1: the most relevant, 0 the least relevant, thus obtaining that each category had only one score. If the result was a tie, the average was used to find the general score. Categories grouped open questions, according to classification proposed by Echeverría [18].

Twelve semi-structured interviews oriented with a guide of questions were carried out in this study. Six of the students belonged to the basic cycle and six were from the professionalization cycle, registered in different terms of the curriculum. Twenty-nine professors of different curricular areas were interviewed: fourteen from the basic cycle and fifteen from the deepening area. Interviewed people expressed with clarity and in a natural way their points of view about formation in communicative competences for the medical action. Once interviews were completed, we continued with focus groups Carey [19], which helped to discuss and widen arguments. With this purpose, a guide on aspects to be analyzed and discussed was sent to participants in order to obtain a more effective participation. Three focus groups were formed with students: one of them had nine students who belonged to different terms of the program. There was a singular participation of seven students of $\mathrm{V}$ term, registered in the subject Medical Act, who became part of the second focus group. The third one was composed by nine students of the subject "Social Pediatrics". Ten professors of the basic cycle and seven professors of professionalization cycle composed another focus group. Professors and students were called by the researcher to participate in this study through e-mails and person to person. The project of this study was submitted before (SIU) University Research System; it was authorized by Bioethics committee of Universidad de Antioquia Medical Research Institute, which also approved the "informed consent." When col- 
lecting the information, recordings were transcribed and then coded and categorized Strauss, [20]. Special emphasis was put on descriptive categories centered on verbal and on non-verbal communication.

In interviews and focus groups, it was found that the importance of communication for the medical act is also a sociological issue, a conclusion to which is easily to arrive observing benefits when an assistance model is properly set up, which allows a physician-patient cooperation relation. Students and professors conceive a patient as an "active agent" of the medical action. The relation established with the physician has the society as its context, which provides interpretative keys of the relational phenomenon. Several initiatives suggest a change in this relation, which overcomes paternalism, which appears in an exaggerated medical authority.

A common proposal for encouraging physician-patient relation resulted from focus groups, in which the word is "empowered," in such a way that it could play an active role, participating in a more appropriate decision making for health. This will improve physician-patient communication and will make the treatment more personalized. Interviewed students and professors perceived that it is necessary to establish a physician-patient relation based on confidence and mutual respect. Wide and panoramic meanings on physician-patient communication, as an indispensable competence in medical education, identified as an important aspect in the deontological character of the medical practice appears in students and professors. In the representative survey proposed to students, the importance of the speech in the physician-patient communication was identified, and they think it is important that this remains on time. However, they stated not to find a satisfactory answer to this issue in the medicine curriculum and pointed that it cannot be properly expressed as a "competence". The students gave high scores to an effective physician-patient communication. Students were asked to choose a score from 1 to 10, (being 10 the highest) to express the importance of formation in communicative competences for the medical act in the curriculum. In order to adjust the analysis, scores 0 and 1 were grouped as not important, 2 to 5 as little important, 6 and 7 as moderately important, 8 and 9 as important, and 10 as very important. To these questions, all survey respondents answered as follows: Table 2 shows a list of the assignments of the students surveyed, about the importance of the doctor-patient communication.

Table 2. Distribution of importance score that U.de A. Medicine School students gave to physician-patient communication as a necessary competence in their medical formation.

\begin{tabular}{cccc}
\hline Values & Frequency & Percentage & Accumulated \\
\hline Very important & 165 & 51.4 & 51.4 \\
Important & 103 & 32.1 & 83.5 \\
Moderately Important & 41 & 12.8 & 96.3 \\
Little Important & 12 & 3.7 & 100.0 \\
Total & 302 & 100.0 & \\
\hline
\end{tabular}




\section{Discussion}

One of the findings in this study was that communication in the medical act is a paramount competence. According to Albert J. Jovell ${ }^{2}$, communication in the medical act is basic since it is an encounter among persons. In the first place, an emotional encounter in an asymmetric context, in which emotional and social intelligences could be dialectically faced. According to this author, these are two competences socially managed in which the first one is a requirement of the second one. From this, personal, labor, and professional success result. They are understood in daily life context, and any labor is exempt of emotional implications. In a second place, it helps to meet the need society has for emotional and human competent professionals. Both students and professors agreed when they state that communication for the medical act shall be a competence in medical education. Professors proposed that formation in this area be transversal to the curriculum, stating that the benefit is not only for the patient but also for the physician, who will see himself emotionally rewarded with the exercise of this competence. The analysis of the survey showed that a large percentage of students who participated in the study (95\%) acknowledged the importance of communication in the medical action. They answered questions related to the short-film Wit (in Latin America this short film has been distributed under the name: Amar la Vida), which was exhibited in the Medicine School at the beginning of Communication subjects, between 2011 and 2015. More than the half of students who answered the survey, (53\%) identified the above mentioned competence as a matter of medical ethics.

Another important finding is that the physician-patient communication should be based on confidence and mutual respect. In focus groups, both students and professors expressed the need for integrating a rigorous and effective learning of physician-patient communication to the curriculum, which bears in mind skills and attitudes to reach effective goals and that, identified as another activity of the medical profession, should be reached in the formation period and overcome the simple manual of manners. Our society demands an assistance and service human communication. In this way, these skills and research techniques will help that the medical action is the expression of the fair deontological task of this profession. From the deliberation of professors' focus group, the statement that for the setting up of such competences is important to form listening skills, non-verbal communication, empathy, and assertiveness in the future physicians appeared, and that such a formation is marked by a strong and decisive rising of human psychology, in which physicians and patients are involved.

Professors also identified the need for studying social and physical guidelines which involve patient's and physician's emotional aspects, in order to understand health and diseases processes as a special point to improve between both, as well as value that the social imaginary provides to disease and to the medical authority. Emotions are directly related with the medical action and become part of the communicative competences of these professionals, in such a way that they condition the quality of the medical action,

${ }^{2}$ President of the Spanish forum of Patients. Director of UAB, General Director of Josep Laporte Foundation, Associate professor of Medicine Schools UAB, 2012. 
make a meaning of it, re-signify it, and help for not losing the ontological horizon of both. In the interview to professors and students, the need for establishing a relation with the patient, based on cordiality, respect and personalized treatment, was emphasized. So, it is necessary, to provide the word for expressing his autonomy, and self-determination capacity and comments his elections or refusals. There are physicians who should prepare to accept patients' participation in decision making in relation to their health.

Furthermore, subjects of the communication area in the medicine undergraduate programs should be focused on humanistic approach. This is the result of the analysis of answers of Universidad de Antioquia School of Medicine, undergraduate programs' students to surveys and interviews of this study, whose purpose is to offer an integrating conception in communication subjects. It was requested by the human phenomenon of axiological and dialectic pair of the word-life-, which is submitted as a pedagogical proposal. If it is true that medical practice has had, among science, knowledge, and disciplines, the fame of being an important task, it is also true that it is an institutionalized practice, which proposes acting norms guiding the subject to mean and rationalize its profession. Therefore, academic situations such as formation in logics and rhetoric are not only important for the medical future, but also for preparing students for using language with expertise and for reaching high persuasion, efficiency, and pertinence goals in the medical action.

\section{Conclusions}

This study confirmed that communication as a generic competence is weakened in the study plan and points out the training in communicative competences for the medical act as urgent. Scientific and social rigor are needed in the curriculum of the undergraduate program of the Medicine Faculty of Universidad de Antioquia. The guidelines and conclusions presented here are the result of interpretations and analyses of students and professors of the aforementioned undergraduate program, with the support of diverse academic sources that were consulted which will allow its socialization in that academic community. The communication for the medical act must be projected in all levels of the medical training, without comparing it with the expertise in the mother tongue, or confusing it with health promotion and prevention. This research provided experiences, reflections and possibilities for the actors of the institutional curriculum in medicine, and its limitation is stated in the researcher's compromise of submitting a pedagogical proposal in a later paper.

The current situation of the health system in Colombia causes the collapse of health assistance and strongly fragments the medical act and subsequently, the doctor-patient communication; this happens because of the re-charges in medicines and the corruption of EPS's. Both patient and doctor are victimized by the coverage, assurance and service quality. This could be improved if the authorities unified the two health regimes in Colombia, along with resources and infrastructure. If these basic necessities are satisfied, the medical act could be competent to be taught to the future medical doctors as 
an effective and humanistic communication. It is advisable for the curriculum committee to know these findings and make the necessary adjustments in the study plan, gradually including the aforementioned training in all the semesters of the undergraduate program. This will benefit the humanistic training of the future doctors as well as the community they attend.

\section{References}

[1] Colombia. Ministerio de Salud y Protección Social (1993) Resolución No 8430 de 1993. Recuperado de: https://www.unisabana.edu.co/fileadmin/Documentos/Investigacion/comite_de_etica/Res_ 8430_1993___Salud.pdf

[2] Declaración de Helsinki de la Asociación Médica Mundial (2008) Principios éticos para las investigaciones médicas en seres humanos. Recuperado de: http://www.wma.net/es/30publications/10policies/b3/17c_es.pdf

[3] Lalonde, M. (Lalonde Report) (1974) A New Perspective on the Health of Canadians. A Working Document. Recuperado de: http://www.phac-aspc.gc.ca/ph-sp/pdf/perspect-eng.pdf

[4] Galindo, L. and Arango, M.E. (2014) De cómo la formación por competencias desarrolla el pensamiento crítico en la educación médica. El caso del pregrado de medicina de la Universidad de Antioquia. Grupo de Investigación EDUSALUD. Universidad de AntioquiaRedipe, Medellín.

[5] González, E.M. (2008) Acerca de un sistema de evaluación por competencias en la formación por ciclos. Universidad de Antioquia, Medellín.

[6] Casasbuenas, L. (2010) Reflexiones en torno a la enseñanza de la comunicación para la salud. Iatreia, 23, 400-404.

[7] Rodríguez, T. (2009) Las habilidades comunicativas en la entrevista médica. Revista Cubana de Medicina Militar, 38, 79-90. Recuperado de: http://scielo.sld.cu/pdf/mil/v38n3-4/mil093-409.pdf

[8] Aguirre Raya, D. (2005) Reflexiones acerca de la competencia comunicativa profesional.

[9] Soto Navarro, Y., Padilla Labrada, M.D. and Solano López, E (2011) La importancia de desarrollar la competencia comunicativa en los profesionales de la salud. Recuperado de: http://www.portalesmedicos.com/publicaciones/articles/4078/1/La-importancia-de-desarrol lar-la-competencia-comunicativa-en-los-profesionales-de-la-salud.html

[10] Watzlawick, P. (1985) La comunicación humana. Herder, Barcelona.

[11] Galeano, M.E. (2007) Estrategias de investigación social cualitativa. La Carreta, Medellín.

[12] Davis, F. (1978) La comunicación no verbal. Alianza Editorial, España.

[13] Feyerabend, P. (1970) Contra el método. Esquema de una teoría anarquista del conocimiento. 2nd Edition, Orbis, Barcelona.

[14] Flórez, R. (2005) Pedagogía del conocimiento. McGraw-Hill, Bogotá.

[15] Foucault, M. (1995) ¿Qué es la crítica? Daimon. Revista Internacional de Filosofía, 11, 5-25. Recuperado de: http://revistas.um.es/daimon/article/view/7261/7021

[16] Freire, P. (2001) La educación como práctica de la libertad. 3rd Edition, Siglo XXI, México.

[17] Arias Valencia, M.M. (2000) La triangulación metodológica: Sus principios, alcances y limitaciones. Investigación y Educación en Enfermería, 18, 13-26.

[18] Echeverría, J. (2003) La revolución tecno-científica. Fondo de Cultura Económica, Madrid. 
[19] Carey, A. (2003) El efecto del grupo en los grupos focales: Planear, ejecutar e interpretar la investigación con grupos focales. En Morse, J., Asuntos críticos en los métodos de investigación cualitativa (pp. 262-280). Universidad de Antioquia, Medellín.

[20] Strauss, A. (2002) Bases de la investigación cualitativa, técnicas y procedimientos para desarrollar la teoría fundamentada. Universidad de Antioquia, Medellín.

Submit or recommend next manuscript to SCIRP and we will provide best service for you:

Accepting pre-submission inquiries through Email, Facebook, LinkedIn, Twitter, etc.

A wide selection of journals (inclusive of 9 subjects, more than 200 journals)

Providing 24-hour high-quality service

User-friendly online submission system

Fair and swift peer-review system

Efficient typesetting and proofreading procedure

Display of the result of downloads and visits, as well as the number of cited articles

Maximum dissemination of your research work

Submit your manuscript at: http://papersubmission.scirp.org/

Or contact jbm@scirp.org 